\title{
A Brief History of Listeria Species, Increasing Trend of Foodborne Listeriosis in Ready-to-Eat Food and their Interaction with Antibiotics and Possible Control Measures
}

\section{Himadri Majumder*}

MSc Microbiology, Birkbeck, University of London, MSc Biotechnology, Bangalore University, Bangalore, India

*Corresponding Author: Himadri Majumder, Flat 3, Churchill House, Leybourne Dell, Benenden, Kent, TN17 4EB, UK. E-mail: hmajumder@yahoo.com
Received: December 16, 2021

Published: January 10, 2022

(C) All rights are reserved by Himadri

Majumder.

\begin{abstract}
Listeriosis is a serious foodborne infection affects mainly the vulnerable groups in the community. Since 1940, twenty-six species with eight subspecies have been identified to date from environment, water and food sources where L. monocytogenes alone is considered as a major human pathogen. Foodborne disease outbreak amidst the COVID-19 pandemic would have added consequences to the economy and public health. Approximately 2.4 million cases of food borne illnesses were reported with more than 16000 hospitalisations in 2018. Between September 2019 and July 2021, there were 57 food products recalled by the UK Food Standards Agency those found contaminated with Listeria monocytogenes. Even though, L. monocytogenes is so far known to be sensitive to antibiotics, their unique antimicrobial resistance to fluoroquinolones, mainly in ready -to- eat food, has been explored together with their durability against commonly used disinfectants in food manufacturing settings. Due to their idiosyncratic growth and survival ability along with the potential of causing serious health consequences including mortality, the article has recommended to set out a "Zero tolerance" to L. monocytogenes detection where current legislated limit in 10 - $100 \mathrm{cfu} / \mathrm{g}$ throughout product shelf life.
\end{abstract}

Keywords: Ready-to-Eat Food Safety; Listeria Monocytogenes; Listeriosis; Antimicrobial Resistance (AMR); Food Hygiene

\section{A brief history of Listeria}

In a report published in 1926, Cambridge scientists E. G. D. Murray, R. A. Webb and M. B. R. Swann, described a new rod-shaped bacterium accounted for sickness of laboratory rabbits titled, "A disease of rabbits characterised by a large mononuclear leucocytosis caused by a hitherto undescribed bacillus Bacterium monocytogenes (n. sp.)". A Scottish bacteriologist, John Hunter Harvey Pirie also reported a similar bacterium isolated from the "Tiger River" and named this as "Listerella hepatolytica" In 1940, but soon comprehends that the sobriquet "monocyogenes" that had been coined by Murray., et al. in 1926, deemed more appropriate. Subsequently, he realized that the genus "Listerella" had also been allocated for Listerrella paradoxa, a slime mould belonging to "Myxomycetes" identified by German botanist E. Jahn. Thence, JHH Pirie proposed the genus to be called "Listeria" in the honour of British surgeon and antiseptic pioneer Sir Joseph Lister [1]. The Genus is akin to Bacillus, Clostridium, Enterococcus, Streptococcus and Staphylococcus with reportedly low guanine and cytosine (G and C) content in the genome, "Listeria monocytogenes" of the family has been the oldest to be identified and is still considered as a major human pathogen, the causative agent of a severe food borne disease called "Listeriosis" [2]. Only six other species of this Genus (excluding $L$. monocytogenes) have been identified until 2010.

The last decade remained eventful in Listeria research. In the past 10 years, with the stupendous advent in biotechnology along with the obtainability of whole genome sequencing and other molecular sequencing technologies have resulted in identification of 17 more species of Listeria (Table 1). According to the List of Pro- 
karyotic names withstanding in Nomenclature (LPSN), founded in 1997, the genre also have maximum two subspecies belonging to Listeria grayi, Listeria ivanovii, Listeria fleischmannii and Listeria cossartiae [3]. The species called Listeria denitrificans isolated by Prevot In 1961 [3] was challenged in 1987 by Rocourt., et al. through 16S ribosomal-RNA study which inveterate that phylogenetically the species has better similarities to Actinomycetes subdivision, therefore was placed in a novel Genus (Gen. Nov.) called Jonesia, in the honour of British microbiologist, Dorothy Jones. Another novel species, Listeria murrayi, capable of fermenting mannitol and reducing nitrate, was proposed by Welshimer and Meredith in 1971 [7]. A review study through DNA hybridisation, ribosomalRNA restriction fragment length polymorphism (rRNA-RFLP) and multilocus enzyme electrophoresis (MEE) of the species Listeria grayi and Listeria murrayi showed that both species are genetically very similar hence proposed to be placed under single species, as L. grayi [8]. However, Sallen., et al. through 23S rRNA sequencing, together with Polymerase Chain Reaction (PCR) amplification of ribosomal DNA gene along with direct cycle sequencing with eubacterial primer, proposed to have two subspecies namely, L. grayi subsp. grayi and L. grayi subsp. murrayi [9].

Investigation by Boerlin., et al. 1992, through DNA homology, Listeria ivanovii was further divided in to two subspecies namely Listeria ivanovii subsp. ivanovii and Listeria ivanovii subsp. londoniensis both of which are distinguishable through biochemical tests, i. e. fermenting of N-acetyl- $\beta$-D-Mannosamine and ribose [10]. Similar molecular techniques have also enabled to determine two subspecies for Listeria fleischmannii such as Listeria fleischmannii subsp. coloradonensis and Listeria fleischmannii subsp. fleischmannii [11]. The latest species to include in the genus are Listeria cossartiae (subsp. cayugensis and subsp. cossartiae) Listeria immobilis, Listeria portnoyi, Listeria rustica, L. farberi, all of which has been identified using whole genome sequencing (WGS) and phylogenetic analysis [5].

Table 1: List of Listeria species identified from diverse source in chronological order.

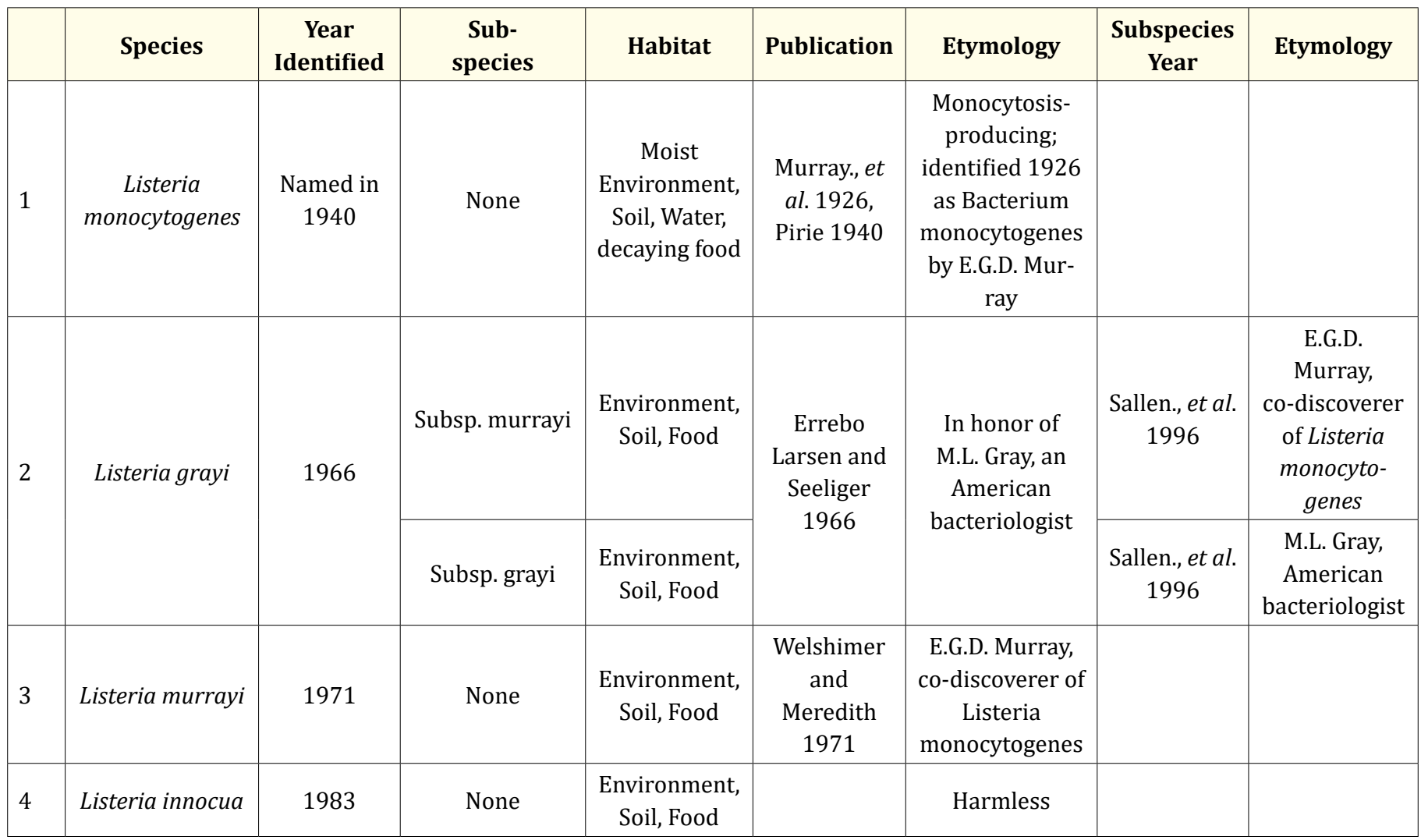


A Brief History of Listeria Species, Increasing Trend of Foodborne Listeriosis in Ready-to-Eat Food and their Interaction with Antibiotics and Possible Control Measures

12

\begin{tabular}{|c|c|c|c|c|c|c|c|c|}
\hline 5 & $\begin{array}{c}\text { Listeria } \\
\text { welshimeri }\end{array}$ & 1983 & None & $\begin{array}{l}\text { Environment, } \\
\text { Soil, Food }\end{array}$ & $\begin{array}{c}\text { Rocourt and } \\
\text { Grimont } \\
1983\end{array}$ & $\begin{array}{l}\text { Named in honor } \\
\text { of Herbert J. } \\
\text { Welshimer, an } \\
\text { American bacte- } \\
\text { riologist }\end{array}$ & & \\
\hline 6 & Listeria seeligeri & 1983 & None & $\begin{array}{l}\text { Environment, } \\
\text { Soil, Food }\end{array}$ & $\begin{array}{c}\text { Rocourt and } \\
\text { Grimont } \\
1983\end{array}$ & $\begin{array}{l}\text { In honor of } \\
\text { Heinz P.R. } \\
\text { Seeliger, a } \\
\text { German } \\
\text { bacteriologist }\end{array}$ & & \\
\hline \multirow[t]{2}{*}{7} & \multirow[t]{2}{*}{ Listeria ivanovii } & 1992 & $\begin{array}{c}\text { Subsp. } \\
\text { londoniensis }\end{array}$ & $\begin{array}{l}\text { Environment, } \\
\text { Soil, Food }\end{array}$ & \multirow[t]{2}{*}{$\begin{array}{l}\text { Seeliger., et } \\
\text { al. 1984, }\end{array}$} & \multirow[t]{2}{*}{$\begin{array}{c}\text { In honor of Ivan } \\
\text { Ivanov, a } \\
\text { Bulgarian } \\
\text { bacteriologist }\end{array}$} & $\begin{array}{l}\text { Boerlin., et } \\
\text { al. } 1992\end{array}$ & $\begin{array}{l}\text { Relating to } \\
\text { London, On- } \\
\text { tario, Canada, } \\
\text { where E. G. D. } \\
\text { Murray and R. } \\
\text { G. E. Murray } \\
\text { worked on } \\
\text { Listeria }\end{array}$ \\
\hline & & 1984 & Subsp. ivanovii & $\begin{array}{l}\text { Environment, } \\
\text { Soil, Food }\end{array}$ & & & $\begin{array}{l}\text { Boerlin., et } \\
\text { al. } 1992\end{array}$ & $\begin{array}{c}\text { In respect of } \\
\text { Ivan Ivanov, } \\
\text { a Bulgarian } \\
\text { bacteriologist }\end{array}$ \\
\hline 8 & Listeria marthii & 2010 & None & $\begin{array}{c}\text { Soil and } \\
\text { Water from } \\
\text { Finger lakes } \\
\text { National } \\
\text { Forest, NY, } \\
\text { USA }\end{array}$ & $\begin{array}{l}\text { Graves., et } \\
\text { al. } 2010\end{array}$ & $\begin{array}{l}\text { Professor Elmer } \\
\text { H. Marth, for } \\
\text { his research } \\
\text { and Contribu- } \\
\text { tions on Listeria } \\
\text { monocytogenes }\end{array}$ & & \\
\hline 9 & $\begin{array}{l}\text { Listeria } \\
\text { rocourtiae }\end{array}$ & 2010 & None & $\begin{array}{l}\text { Pre-cut } \\
\text { Lettuce in } \\
\text { Austria }\end{array}$ & $\begin{array}{l}\text { Leclercq., et } \\
\text { al. } 2010\end{array}$ & $\begin{array}{c}\text { Jocelyne } \\
\text { Rocourt, a } \\
\text { French } \\
\text { bacteriologist, } \\
\text { whose work } \\
\text { had a major } \\
\text { impact on the } \\
\text { taxonomy } \\
\text { of the genus } \\
\text { Listeria }\end{array}$ & & \\
\hline \multirow{2}{*}{10} & \multirow{2}{*}{$\begin{array}{c}\text { Listeria } \\
\text { fleischmannii }\end{array}$} & \multirow{2}{*}{2013} & $\begin{array}{c}\text { Subsp. } \\
\text { fleischmannii }\end{array}$ & \multirow{2}{*}{$\begin{array}{c}\text { Environment } \\
\text { and Food, i. e } \\
\text { Cheese }\end{array}$} & \multirow{2}{*}{$\begin{array}{l}\text { Bertsch., et } \\
\text { al. } 2013\end{array}$} & \multirow{2}{*}{$\begin{array}{l}\text { Scientist } \\
\text { Professor } \\
\text { Wilhelm } \\
\text { Fleischmann, } \\
\text { the founder of } \\
\text { Dairy Science } \\
\text { and Technology }\end{array}$} & $\begin{array}{l}\text { den Bakker., } \\
\text { et al. } 2013\end{array}$ & $\begin{array}{c}\text { Professor } \\
\text { Wilhelm } \\
\text { Fleischmann, } \\
\text { the founder of } \\
\text { Dairy Science } \\
\text { and } \\
\text { Technology } \\
\end{array}$ \\
\hline & & & $\begin{array}{c}\text { subsp. } \\
\text { coloradonensis }\end{array}$ & & & & $\begin{array}{l}\text { den Bakker., } \\
\text { et al. } 2013\end{array}$ & $\begin{array}{l}\text { Belonging } \\
\text { to Colorado, } \\
\text { the USA state } \\
\text { from which } \\
\text { the type } \\
\text { strain was } \\
\text { first isolated }\end{array}$ \\
\hline
\end{tabular}

Citation: Himadri Majumder. "A Brief History of Listeria Species, Increasing Trend of Foodborne Listeriosis in Ready-to-Eat Food and their Interaction with Antibiotics and Possible Control Measures". Acta Scientific Microbiology 5.2 (2022): 10-19. 
A Brief History of Listeria Species, Increasing Trend of Foodborne Listeriosis in Ready-to-Eat Food and their Interaction with Antibiotics and Possible Control Measures

\begin{tabular}{|c|c|c|c|c|c|c|c|}
\hline 11 & $\begin{array}{l}\text { Listeria } \\
\text { weihenstepha- } \\
\text { nensis }\end{array}$ & 2013 & None & Water & $\begin{array}{l}\text { Lang Halter., } \\
\text { et al. } 2013\end{array}$ & $\begin{array}{l}\text { Freising/Wei- } \\
\text { henstephan } \\
\text { in southern } \\
\text { Germany, where } \\
\text { the type strain } \\
\text { was identified } \\
\text { in aquatic plant } \\
\text { called "Lemna } \\
\text { trisulca" in } \\
\text { freshwater } \\
\text { pond }\end{array}$ & \\
\hline 12 & L. aquatica & 2014 & None & Water & $\begin{array}{l}\text { Den Bakker., } \\
\text { et al. } 2014\end{array}$ & Aqua or water & \\
\hline 13 & L. cornellensis & 2014 & None & $\begin{array}{l}\text { Agri and } \\
\text { Natural Env }\end{array}$ & $\begin{array}{l}\text { Den Bakker., } \\
\text { et al. } 2014\end{array}$ & $\begin{array}{c}\text { Cornell } \\
\text { University } \\
\text { where most of } \\
\text { the research } \\
\text { were performed }\end{array}$ & \\
\hline 14 & $\begin{array}{l}\text { Listeria } \\
\text { floridensis }\end{array}$ & 2014 & None & $\begin{array}{c}\text { Agricultural } \\
\text { and natural } \\
\text { environments }\end{array}$ & $\begin{array}{l}\text { Den Bakker., } \\
\text { et al. } 2014\end{array}$ & $\begin{array}{l}\text { State of Florida } \\
\text { in the USA, } \\
\text { where the } \\
\text { strain was first } \\
\text { isolated }\end{array}$ & \\
\hline 15 & Listeria riparia & 2014 & None & $\begin{array}{c}\text { Agricultural } \\
\text { and natural } \\
\text { environments }\end{array}$ & $\begin{array}{l}\text { Den Bakker., } \\
\text { et al. } 2014\end{array}$ & $\begin{array}{l}\text { The bank of a } \\
\text { river or stream }\end{array}$ & \\
\hline 16 & $\begin{array}{l}\text { Listeria } \\
\text { grandensis }\end{array}$ & 2014 & None & $\begin{array}{c}\text { Agricultural } \\
\text { and natural } \\
\text { environments }\end{array}$ & $\begin{array}{l}\text { Den Bakker., } \\
\text { et al. } 2014\end{array}$ & $\begin{array}{l}\text { County Grand } \\
\text { where the } \\
\text { strain was first } \\
\text { isolated }\end{array}$ & \\
\hline 17 & L. booriae & 2015 & None & $\begin{array}{c}\text { Food } \\
\text { processing } \\
\text { environment }\end{array}$ & $\begin{array}{l}\text { Weller., et al. } \\
\quad 2015\end{array}$ & $\begin{array}{l}\text { Kathryn Boor, } \\
\text { A food scien- } \\
\text { tist, for her } \\
\text { contribution } \\
\text { to understand } \\
\text { the biology of } \\
\text { Listeria }\end{array}$ & \\
\hline 18 & $\begin{array}{c}\text { Listeria } \\
\text { newyorkensis }\end{array}$ & 2015 & None & $\begin{array}{c}\text { Food } \\
\text { processing } \\
\text { Environment }\end{array}$ & $\begin{array}{l}\text { Weller., } \text { et al. } \\
\quad 2015\end{array}$ & $\begin{array}{l}\text { Belonging to } \\
\text { the state of New } \\
\text { York in the USA }\end{array}$ & \\
\hline 19 & Listeria goaensis & 2018 & None & $\begin{array}{l}\text { Mangrove } \\
\text { swamps }\end{array}$ & $\begin{array}{c}\text { Doijad., et } \\
\text { al. } 2018\end{array}$ & $\begin{array}{l}\text { State of Goa in } \\
\text { India, the place } \\
\text { from which the } \\
\text { isolate } \\
\text { originated }\end{array}$ & \\
\hline 20 & $\begin{array}{l}\text { Listeria } \\
\text { thailandensis }\end{array}$ & 2019 & None & $\begin{array}{l}\text { Food sample, } \\
\text { i. e. Fried } \\
\text { chicken }\end{array}$ & $\begin{array}{l}\text { Leclercq., et } \\
\text { al. } 2019\end{array}$ & $\begin{array}{l}\text { Thailand, the } \\
\text { country where } \\
\text { the type of } \\
\text { strain was origi- } \\
\text { nally isolated }\end{array}$ & \\
\hline
\end{tabular}




\begin{tabular}{|c|c|c|c|c|c|c|c|c|}
\hline 21 & $\begin{array}{c}\text { Listeria } \\
\text { valentina }\end{array}$ & 2020 & None & $\begin{array}{l}\text { Utensils, i. e. } \\
\text { water trough } \\
\text { and faeces of } \\
\text { healthy sheep }\end{array}$ & $\begin{array}{l}\text { Quereda., et } \\
\text { al. } 2020\end{array}$ & $\begin{array}{l}\text { Valencia, the } \\
\text { region of Spain } \\
\text { where the type } \\
\text { of strain was } \\
\text { isolated }\end{array}$ & & \\
\hline \multirow{2}{*}{22} & \multirow{2}{*}{$\begin{array}{c}\text { Listeria } \\
\text { cossartiae }\end{array}$} & \multirow{2}{*}{2021} & $\begin{array}{c}\text { subsp. } \\
\text { cayugensis }\end{array}$ & $\begin{array}{l}\text { Agricultural } \\
\text { water and } \\
\text { natural } \\
\text { environments }\end{array}$ & $\begin{array}{l}\text { Carlin., et al. } \\
\quad 2021\end{array}$ & \multirow{2}{*}{$\begin{array}{c}\text { Dr. Pascale } \\
\text { Cossart for her } \\
\text { research contri- } \\
\text { butions toward } \\
\text { our understand- } \\
\text { ing } \\
\text { of Listeria } \\
\text { monocytogenes } \\
\text { virulence }\end{array}$} & $\begin{array}{l}\text { Carlin., et al. } \\
\quad 2021\end{array}$ & $\begin{array}{l}\text { Cayuga Lake, } \\
\text { one of the } \\
\text { Finger Lakes } \\
\text { in Central } \\
\text { New York, } \\
\text { and adjacent } \\
\text { to Ithaca, USA, } \\
\text { where Cornell } \\
\text { University is } \\
\text { located }\end{array}$ \\
\hline & & & $\begin{array}{c}\text { subsp. } \\
\text { cossartiae }\end{array}$ & $\begin{array}{l}\text { Agricultural } \\
\text { water and } \\
\text { natural } \\
\text { environments }\end{array}$ & $\begin{array}{l}\text { Carlin., et al. } \\
\quad 2021\end{array}$ & & $\begin{array}{l}\text { Carlin., et al. } \\
\quad 2021\end{array}$ & $\begin{array}{c}\text { Dr. Pascale } \\
\text { Cossart for } \\
\text { her research } \\
\text { contributions } \\
\text { toward our } \\
\text { understand- } \\
\text { ing of Listeria } \\
\text { monocyto- } \\
\text { genes } \\
\text { virulence }\end{array}$ \\
\hline 23 & $\begin{array}{c}\text { Listeria } \\
\text { immobilis }\end{array}$ & 2021 & None & $\begin{array}{l}\text { Agricultural } \\
\text { water and } \\
\text { natural } \\
\text { environments }\end{array}$ & $\begin{array}{l}\text { Carlin., et al. } \\
\quad 2021\end{array}$ & $\begin{array}{l}\text { Non-motile } \\
\text { named for the } \\
\text { species distinct } \\
\text { lack of motil- } \\
\text { ity, an atypical } \\
\text { characteristic } \\
\text { of sensu stricto } \\
\text { Listeria species }\end{array}$ & & \\
\hline 24 & Listeria portnoyi & 2021 & None & $\begin{array}{l}\text { Agricultural } \\
\text { water and } \\
\text { natural } \\
\text { environments }\end{array}$ & $\begin{array}{l}\text { Carlin., et al. } \\
\quad 2021\end{array}$ & $\begin{array}{l}\text { Dr. Daniel } \\
\text { Portnoy for his } \\
\text { contributions } \\
\text { to our under- } \\
\text { standing of L. } \\
\text { monocytogenes } \\
\text { virulence and } \\
\text { pathogenicity }\end{array}$ & & \\
\hline 25 & Listeria rustica & 2021 & None & $\begin{array}{l}\text { Agricultural } \\
\text { water and } \\
\text { natural } \\
\text { environments }\end{array}$ & $\begin{array}{l}\text { Carlin., et al. } \\
\quad 2021\end{array}$ & $\begin{array}{l}\text { Of rural origin' } \\
\text { named to } \\
\text { commemorate } \\
\text { the rural } \\
\text { location from } \\
\text { which this } \\
\text { species was } \\
\text { isolated }\end{array}$ & & \\
\hline
\end{tabular}


A Brief History of Listeria Species, Increasing Trend of Foodborne Listeriosis in Ready-to-Eat Food and their Interaction with Antibiotics and Possible Control Measures

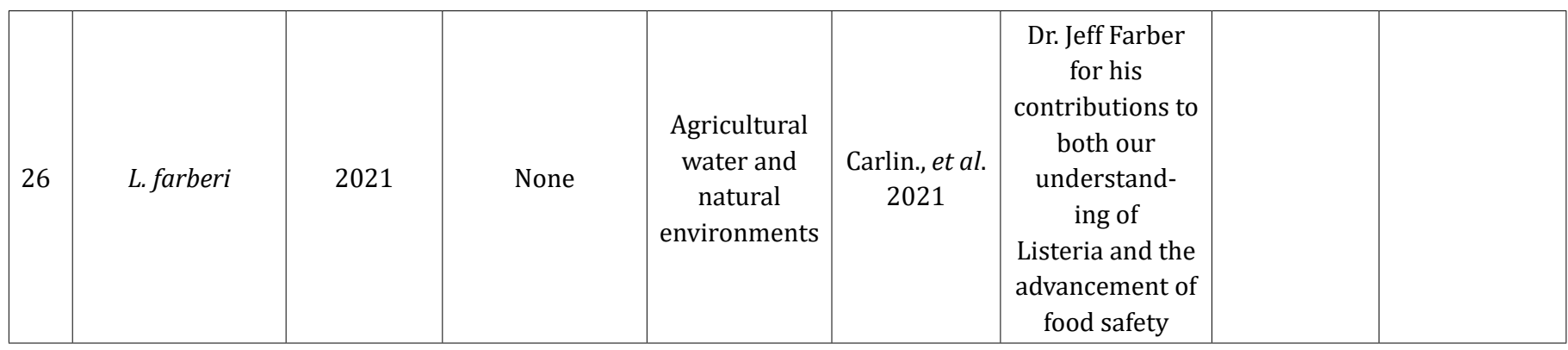

Table 1: List of Listeria species identified from diverse source in chronological order.

Ready-to-eat food business and Food Borne Listeriosis

The UK food and drink industry, so far, the biggest manufacturing sector which is larger than the automotive and aerospace industries combined. The industry alone contributed more than $£ 28$ billion in 2018 to the national economy as reported by the food and drink federation (https://www.fdf.org.uk/statsataglance.aspx). Consumption of ready to eat foods are skyrocketing to meet the pace of the busy world. According to the IGD forecast, a food and consumer goods think tank, the UK food- to- go business sector to grow by $26.4 \%$ by 2024 [12]. However, threat of food borne illnesses pose to obscure the ongoing achievements. The food standards agency (FSA) has estimated that food borne illnesses have costed approximately $£ 9.2$ billion in 2018 that includes human misery and affliction in monetary denomination [16]. During the bleak era of the COVID-19 pandemic, it is expected that other sources of illnesses, mainly those originate through food ingestion, are not overshadowed, in order to keep the hospital beds less occupied for the patient who needs urgent treatment. There were approximately 2.4 million cases of food borne illnesses with more than sixteen thousand hospitalisations reported in the UK in 2018 [16]. Listeriosis is a severe foodborne illness-particularly to the pregnant women causing miscarriage, abortion even results in stillbirth and high rate of mortality to elderly and immunocompromised individuals which is estimated to be greater than 30\% by EFSA in 2015 [13]. Incubation period or the onset of the disease caused by Listeria monocytogenes can be as long as 70 days [14]. These foodborne pathogens are gram positive, non-spore forming, non-capsulated, rod-shaped bacteria which is ubiquitous as a saprophytic pathogen in soil, water, sewage and in plant decaying. They also fall in the group called "psychrotrophs" for their resilience to refrigeration temperature [15,27]. These moderate "halophiles" [16] with the ability to withstand up to $20 \%$ salt and capable of developing biofilms in food contact surfaces made of even plastic and stainless steel [27]. The pathogen has so far been characterized in to four major serotypes $1 / 2 \mathrm{a}, 1 / 2 \mathrm{~b}, 1 / 2 \mathrm{c}$ and $4 \mathrm{~b}$, three of which, except $1 / 2 c$, are considered as important food-borne strains [29]. During the period of lockdown, most of the businesses have to cope with the stressed supply chain with limited workforce. It is, therefore, a challenge maintaining a tensile food safety supply chain in order to mitigate the threat of hunger and food insecurity [30].

Increasing trend of Listeriosis in ready- to- eat foods

The European Union has seen 60\% rise in Listeria related infections with 270 fatalities in 7 years from 2008 to 2015 as a result of surging demand in ready-to-eat foods [31]. Infections caused by Listeria pathogen were accounted for $16 \%$ deaths, the highest figure among other bacterial food borne diseases such as, Campylobacter and C. perfringens infection [18]. A review of the pathogen's outbreak reported in the ProMed (global outbreak reporting system) between 1996 and 2018 has been carried out by Desai and team in 2019. Listeria events reported by thirty countries showed a clear increase in the Listeriosis cases between 2012 and 2018 linked with long-established food vehicles, mainly, ready to eat foods, soft cheeses and smoked seafood [17]. Whole genome sequencing has confirmed that the largest outbreak of Listeriosis in South Africa between 2017 and 2018 also shared the links with ready-to-eat processed meat [32].

The Food Standards Agency, UK has alerted 57 ready -to eat products those were contaminated with L. monocytogenes were recalled by the manufacturer or retailer in a year between September 2019 and mid 2021 (Table 2).

New foods associated with the pathogen, such as, cantaloupe melon, asparagus soup, frozen fruits and vegetables including 
A Brief History of Listeria Species, Increasing Trend of Foodborne Listeriosis in Ready-to-Eat Food and their Interaction with Antibiotics and Possible Control Measures

\begin{tabular}{|c|c|c|c|}
\hline $\begin{array}{l}\text { Alert Date } \\
\text { by Food } \\
\text { Standards } \\
\text { Agency }\end{array}$ & $\begin{array}{l}\text { Manufacturer/ } \\
\text { Retailer/Brand }\end{array}$ & $\begin{array}{l}\text { Number } \\
\text { of } \\
\text { Product } \\
\text { Recalled }\end{array}$ & $\begin{array}{c}\text { Product } \\
\text { Type }\end{array}$ \\
\hline 14-Sep-19 & Soupologie & 3 & $\begin{array}{c}\text { Soup containing } \\
\text { Carrot, Red pepper, } \\
\text { Broccoli, Pea, Basil, } \\
\text { Leek }\end{array}$ \\
\hline 20-Sep-19 & Pipers Crisps & 7 & $\begin{array}{c}\text { Anglesey Sea Salt } \\
\text { and Karnataka } \\
\text { Black Pepper Crisps }\end{array}$ \\
\hline 13-Dec-19 & Yaadgaar & 1 & $\begin{array}{l}\text { Rasmalai (Indian } \\
\text { style sweet) }\end{array}$ \\
\hline 09-May-20 & Morrisons & 10 & $\begin{array}{l}\text { Market street living } \\
\text { herbs (Basil, Chives, } \\
\text { Coriander, Dill, } \\
\text { Parsley, Mint and } \\
\text { Thyme) }\end{array}$ \\
\hline 31-Jul-20 & Bread Spread & 21 & $\begin{array}{l}\text { Chicken containing } \\
\text { sandwiches, wraps, } \\
\text { tortilla, torpido, } \\
\text { French stick, roll } \\
\text { and baguettes }\end{array}$ \\
\hline 10-Sep-20 & Faughan Foods & 1 & $\begin{array}{l}\text { Glensallagh Roast } \\
\text { Chicken }\end{array}$ \\
\hline 21-Sep-20 & Dunnes Stores & 2 & $\begin{array}{c}\text { Cooked Chiicken } \\
\text { and Tikka Style } \\
\text { Chicken }\end{array}$ \\
\hline 21-Sep-20 & Faughan Foods & 2 & $\begin{array}{c}\text { Glensallagh Roast } \\
\text { and Tikka Style } \\
\text { Chicken Brest } \\
\text { pieces }\end{array}$ \\
\hline $30-$ Oct-20 & Bettinehoeve & 5 & Goats Cheese \\
\hline 14-Jan-21 & Tesco & 1 & Finest Taleggio \\
\hline 09-June-21 & $\begin{array}{l}\text { Cheese on the } \\
\text { Wey }\end{array}$ & 1 & Blue Millie Cheese \\
\hline 27-July-21 & Cahill's Farm & 3 & $\begin{array}{l}\text { Several Cheese } \\
\text { Products }\end{array}$ \\
\hline
\end{tabular}

Table 2: Ready- to- eat foods recalled by the Food Standards Agency.

broccoli, cauliflower, peas, onions, peppers, sweet potatoes, corn, blueberries, cranberries, peaches, raspberries, strawberries, ice creams, mashed potatoes, sprouts, chopped celeries, mashed potatoes, sandwiches and wraps have been added to the list lengthening traditionally known food vehicles such as soft cheeses, dairy products, pates, smoked seafoods and sausages [17].
Antimicrobial resistance (AMR) in Listeria monocytogenes

Antibiotics intervention is often deemed necessary to treat Listeria infection. So far reports indicate that Listeria monocytogenes is generally susceptible against antimicrobials used to treat Gram-positive bacteria. However, evidence higher rate of preponderance of the pathogen associated with foods and the emergence antibiotic resistance are posing concern to the public health [26]. A number of recent studies have reported that at least $30 \%$ isolates from ready-to-eat food origin (garlic bread, cheese, frozen bread, fermented sausage and other ready-to- eat foods) manifested multiple antibiotic resistance against fluoroquinolone (Ciprofloxacin), macrolide (Erythromycin) and Nitrofurantoin those belonged to $1 / 2 \mathrm{a}, 1 / 2 \mathrm{~b}$ and $4 \mathrm{~b}$ strains of Listeria monocytogenes [13] including higher resistance found against oxacillin, kanamycin, levofloxacin, teicoplanin and amoxicillin [26].

There are several ways the microorganisms may attain antimicrobial resistant property, such as, by acquiring genes through horizontal genes transfer, by altering metabolic pathway, by genetic mutations to decreasing cellular intake of antimicrobial agents and by acquiring cellular efflux pump to extrude antimicrobials from the cells. Efflux mechanism so far been studied in detail has been claimed to present in all bacterial species [19]. It is interesting that the studies carried out by Komora, N., et al. in 2017 and Olaimat, A. N., et al. in 2018, both reporting antimicrobial resistance of Listeria monocytogenes to fluroquinolones. Intriguing to follow that both food and clinical origins were more tolerant to acid and osmotic stresses [13]. The team also looked into a suspected special behavioural characteristic called "active efflux". The mechanism was previously spotted and described by Hiroshi Nikaido in 1994 as a mechanism of drug resistance. Presence of the efflux mechanism in food isolates were well revealed, specifically, to fluoroquinolone. They also showed active efflux of benzalkonium chloride (quats or quaternary ammonium compounds) and hydrogen peroxide, which are used as primary disinfectants to many food industries and often in the ready to eat foods settings. Genes associated with benzalkonium chloride efflux such as, mdrl been documented by Romanuva., et al. in 2006 which was again proved in 2015 by the work of Tamburro M., et al. reporting of $60 \%$ increase in transcription of efflux mechanism in L. monocytogenes using sublethal dose of the compound. It is, hence, necessary to take lessons in order to tackle and invigilate this food borne pathogen in the food productions. 
Control of Listeria monocytogenes and species in factory settings

So far, as a pathogen, Listeria monocytogenes has broadly been recognised as sensitive to $\mathrm{pH}$ lower than 3.0, increasing sensitivity by addition of $5 \%$ ethanol $(\mathrm{V} / \mathrm{V})$ as reported by Barker and Park in 2001. They are believed to have sensitivity to organic acids and osmotic stress too [13]. In a study, we have verified the claim at a lower pH using Listeria innocua NCTC 11288, detail of the study remains undisclosed according to company's business policy. Psychrotrophic property of these bacteria provides them with advantages to outcompete other mesophilic bacteria. It is thus important to clear out every recess with effective terminal disinfectant. Disinfectant based on sodium hypochlorite, in most cases, is the choice of disinfectant due to their strong disinfectant property, ease of availability, and cost effectiveness. However, environmental impact of the hypochlorite is now well understood. Therefore, USDA and other government authorities, including the Department of food and rural affairs, UK, have approved broad spectrum disinfectants [33] based on malic acid, sulphamidic acid, sodium toluenesulphonate, dipotassium peroxodisulphate and dipentene. Also, quarternary ammonium with amphoteric compound based terminal disinfectants provide good control against Listeria burden in the factory. Hazard analysis and critical control point (HACCP) guidelines provide important role in identifying, eliminating and monitoring of critical production, packaging, storage and distribution process. Furthermore, routine sampling and testing of the raw materials, in-line pro- duction sampling, finished products, pre and post operational sampling of various equipment, blade and mixers shed light on the trend of the pathogen activity [15]. In my long professional experience, it was evinced that robust monitoring system and planned environmental swabbing could be key index of factory and premises hygiene and detecting Listeria species. It is also important to easily identify the species detected in the factory premises, especially in the high care production. Enzyme linked immunofluorescence assays are semi-automated techniques that are highly sensitive and less time consuming than the traditional plate incubation method. Biochemical identification system provides as a useful tool in the early species identification. There are a few biotechnology companies have their own brand available in the market (i. e. Oxoid, Microgen etc.), however, Analytical Profile Index web based (API system) developed by bioMerieux, France deemed to be highly specific, although all of the identification system relies on the microorganisms' s ability of sugar fermentation and enzymatic reaction that renders colour change. With the help of a specially adapted web-based database, API Listeria system differentiate L. monocytogenes to other species through a colour change reaction with Dimethyl sulfoxide and Fast Blue B indicator along with the score obtained through supplementary sugar fermentation in 18 - 24 hours aerobic incubation at $37 \pm 1^{\circ} \mathrm{C}$ (Table 3 ).

\begin{tabular}{|c|c|c|c|c|c|c|c|c|c|c|c|c|c|}
\hline \multicolumn{14}{|c|}{ API Listeria identification (bioMerieux, Marcy-l'Etoile) } \\
\hline & Tests & DIM & ESC & QMAN & DARL & XYL & RHA & MDG & RIB & G1P & TAG & $\beta$-HEM & \\
\hline & $\begin{array}{c}\text { Active } \\
\text { Ingredients }\end{array}$ & $\begin{array}{l}\text { Enzyme } \\
\text { Substrate }\end{array}$ & $\begin{array}{l}\text { Esculin } \\
\text { Ferric } \\
\text { Sulphate }\end{array}$ & $\begin{array}{l}\text { 4-Nitrophenyl } \\
\text { - } \alpha \mathrm{D} \text {-manno- } \\
\text { pyranoside }\end{array}$ & $\begin{array}{c}\text { D- } \\
\text { Arabitol }\end{array}$ & $\begin{array}{c}\text { D- } \\
\text { Xylose }\end{array}$ & $\begin{array}{l}\text { L-Rham- } \\
\text { nose }\end{array}$ & $\begin{array}{c}\text { Methyl- } \alpha \mathrm{D}- \\
\text { glucopyranoside }\end{array}$ & $\begin{array}{l}\text { D-Ri- } \\
\text { bose }\end{array}$ & $\begin{array}{l}\text { Glucose- } \\
\text { 1-Phos- } \\
\text { phate }\end{array}$ & $\begin{array}{l}\text { D-Taga- } \\
\text { rose }\end{array}$ & $\begin{array}{c}\text { Beta } \\
\text { Haemoly- } \\
\text { sis } \\
\text { (If Present) } \\
\text { (no Score) } \\
\end{array}$ & \\
\hline & Reaction & $\begin{array}{l}\text { To differentiate } \\
\text { between } \\
L . \\
\text { monocytogenes } / L \text {. } \\
\quad \text { innocua }\end{array}$ & $\begin{array}{c}\text { Esculin } \\
\text { Hydrolysis }\end{array}$ & $\alpha$-Mannosidase & \multicolumn{7}{|c|}{ Acidification of sugars } & & \\
\hline \multirow[b]{2}{*}{ Result } & Positive (+) & Orange & Black & Yellow & \multicolumn{7}{|c|}{ Yellow/Yellow Orange } & & \\
\hline & Negative (-) & $\begin{array}{c}\text { Pale Orange/ } \\
\text { Pink-beige/Grey } \\
\text { Beige }\end{array}$ & $\begin{array}{l}\text { Pale Yel- } \\
\text { low }\end{array}$ & Colourless & \multicolumn{7}{|c|}{ Red/Orang Red } & & \\
\hline \multicolumn{2}{|c|}{$\begin{array}{l}\text { L. monocytogenes } \\
\text { (ATCC 19115-4B) }\end{array}$} & - & + & + & + & - & + & + & - & - & - & + & \multirow{6}{*}{$\begin{array}{l}\text { Typical } \\
\text { Reac- } \\
\text { tions } \\
\text { after } \\
\text { incuba- } \\
\text { tion }\end{array}$} \\
\hline \multicolumn{2}{|c|}{$\begin{array}{l}\text { L. ivanovii (ATCC } \\
700402 \text { ) }\end{array}$} & + & + & - & + & + & - & + & + & \pm & \pm & - & \\
\hline \multicolumn{2}{|c|}{$\begin{array}{l}\text { L. inпосиа } \\
\text { (NCTC11288) }\end{array}$} & + & + & + & + & - & + & + & - & - & - & - & \\
\hline \multicolumn{2}{|c|}{$\begin{array}{l}\text { L. monocytogenes } \\
\text { (Field Strain) }\end{array}$} & - & + & + & + & - & + & + & - & - & - & + & \\
\hline \multicolumn{2}{|c|}{$\begin{array}{l}\text { L. seeligeri (Field } \\
\text { Strain) }\end{array}$} & + & + & - & + & + & - & + & - & - & - & - & \\
\hline \multicolumn{2}{|c|}{$\begin{array}{l}\text { L. innocua (Field } \\
\text { Strain) }\end{array}$} & + & + & + & + & - & + & + & - & - & - & - & \\
\hline
\end{tabular}

Table 3: Biochemical Identification of Listeria species using API Listeria kit.

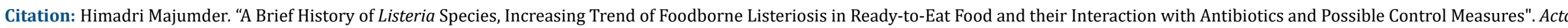
Scientific Microbiology 5.2 (2022): 10-19. 
Molecular techniques are now more readily available to determine possible sources of contamination, tracking the manufacturer facility and in the testing laboratory. One of the techniques called multi-locus sequence typing (MLST) pioneered by Maiden., et al. in 1998 is now readily available as ribosomal-MLST for extensive characterisation of microorganisms from the field to strain [22]. The gene cluster associated with the virulence of $L$. monocytogenes comprises of prfA, plcA, hly, mpl, actA and plcB genes [24]. Geographical tracking is also of the pathogen is also now possible through this molecular technique [25]. Many well-respected laboratories dedicated to food science are now providing reasonably priced commercial identification and characterisation service using automated molecular systems developed by various biotechnology companies.

\section{Discussion and Conclusion}

Product recall is an expensive game for both manufacturer and retailer and the public health is even greater. Many years of personal experience in this sector have taught me that it is impossible to eliminate Listeria pathogen from the factory environment. Therefore, controlling the pathogen through proper risk assessment, monitoring, prompt identification capability and quality assurance are the key to minimise infections in the dynamic ready to eat food industry. It is also may be appropriate to mention as the pathogen is a major public health concern with significant clinical manifestations, high mortality rate and a widely variable incubation period between few days up to 90 days (WHO.int). Current legislation in the UK and in the EU (EC No. 2073/2005) does not explicitly require "Zero Tolerance" for the pathogen. It is deemed necessary to consider an amendment to the legislation and should address this Listeria monocytogenes by including it to the list of major food pathogens, in line with, thermotolerant Camppylobacter species, E. coli 0157 and VTEC producing strain, Salmonella species and Vibrio cholerae, which are categorised as "must be absent in food" (at least $25 \mathrm{~g}$ tested). All other species of the genus (Listeris), enumeration limit of between $10-100$ colony forming unit per gram food may be retained as these are not deemed pathogenic to humans. The Food and Drug Administration (FDA) has revised its draft guidance in 2017 suggesting $100 \mathrm{cfu} / \mathrm{g}$ of Listeria limit for RTE food in which L. monocytogenes cannot grow [28]. The integrity and focus of the management system and its culture also influence the Listeria food safety of a company. A competent food safety team should comprise of individuals with proper training, look out for details and sharp senses to spot anomalies. The team thereby should have the freedom from conflict of interest of other departments and must be free from intimidation from the higher management. It is also indeed necessary to monitor intrinsic molecular process of the microorganisms that renders them to become drug resistant and kept under constant scrutiny. In the wake of a greatest pandemic of human history alongside growing antibiotic resistance of various pathogens, it is now absolutely necessary to implement knowledge straight from the horse's mouth in to the manufacturing culture. As the COVID-19 pandemic infringed into everyday life until a proper treatment or effective vaccine is discovered, it is of utmost importance to concentrate on food chain safety to keep the hospitals less occupied with food borne outbreak. At the same time, it is immense necessary to ensure providing safe food to the table, where many vulnerable would need to survive on the supply of ready to eat foods alone.

\section{Conflict of Interest}

The article is free from any conflict of interest. Solely written as a science enthusiast to communicate with the scientific community and for the betterment of the food safety.

Bibliography

1. Gibbons NE. "Listeria Pirie-Whom Does It Honor?" International Journal of Systematic Bacteriology 22 (1972): 1-3.

2. McLauchlin J. "The identification of Listeria species". International Journal of Food Microbiology 38 (1997): 77-81.

3. Nwaiwu 0. "What are the recognized species of the genus Listeria?" Access Microbiology 2 (2020): 3-4.

4. Carlin CR., et al. "Listeria cossartiae sp. Nov., listeria immobilis sp. nov., listeria portnoyi sp. nov. and listeria rustica sp. nov., isolated from agricultural water and natural environments". International Journal of Systematic and Evolutionary Microbiology (2021): 71.

5. Jose' A Va'zquez-Boland., et al. "Listeria Pathogenesis and Molecular Virulence Determinants". Clinical Microbiology Reviews (2001): 584-640.

6. Welshimer HJ and Meredith AL. "Listeria murrayi. sp. n.: a Nitrate-Reducing Mannitol-Fermenting Listeria". International Journal of Systematic Bacteriology 21 (1971): 3-7.

7. Rocourt J., et al. "Assignment of Listeria grayi and Listeria murrayi to a single species, Listeria grayi, with a revised description of Listeria grayi". International Journal of Systematic Bacteriology 42 (1992): 171-174.

8. Sallen B., et al. "Comparative analysis of $16 \mathrm{~S}$ and $23 \mathrm{~S}$ rRNA sequences of Listeria species". International Journal of Systematic Bacteriology 46 (1996): 669-674. 
9. Boerlin P., et al. "Listeria ivanovii subsp. londoniensis subsp. Nov". International Journal of Systematic Bacteriology 42 (1992): 69-73.

10. Den Bakker HC., et al. "Genome sequencing identifies Listeria fleischmannii subsp. coloradonensis subsp. nov., isolated from a ranch". International Journal of Systematic and Evolutionary Microbiology 63 (2013): 3257-3268.

11. Komora N., et al. "Survival of Listeria monocytogenes with different antibiotic resistance patterns to food-associated stresses". International Journal of Food Microbiology, 245 (2017): 79-87.

12. Goulet V., et al. "What is the incubation period for listeriosis?" BMC Infectious Diseases (2013): 13.

13. Kornacki JL. "Detecting Sources of Listeria monocytogenes in the Ready-To-Eat Food Processing Environment". Kornacki Microbiology Solutions (2012): 1-15.

14. Kim J., et al. "Halophilic and Osmophilic Microorganisms". Compendium of Methods for the Microbiological Examination of Foods (2015).

15. Desai AN., et al. "Changing epidemiology of Listeria monocytogenes outbreaks, sporadic cases, and recalls globally: A review of ProMED reports from 1996 to 2018". International Society for Infectious Diseases 84 (2019): 48-53.

16. Daniel N., et al. "The Burden of Foodborne Disease in the UK 2018". Food Standards Agency (2020).

17. Tenover FC. "Mechanisms of antimicrobial resistance in bacteria". American Journal of Infection Control 34.5 (2006).

18. Barker $\mathrm{C}$ and Park SF. "Sensitization of Listeria monocytogenes to Low pH, Organic Acids, and Osmotic Stress by Ethanol". Applied and Environmental Microbiology 67.4 (2001): 1594-1600.

19. Maiden MCJ., et al. "Multilocus sequence typing: A portable approach to the identification of clones within populations of pathogenic microorganisms". Proceedings of the National Academy of Sciences of the United States of America 95.6 (1981): 3140-3145.

20. Jolley KA., et al. "Ribosomal multilocus sequence typing: Universal characterization of bacteria from domain to strain". Microbiology 158.4 (2012): 1005-1015.

21. Sun J., et al. "Bacterial multidrug efflux pumps: Mechanisms, physiology and pharmacological exploitations". Biochemical and Biophysical Research Communications 453.2 (2014): 254267.
22. Poimenidou SV., et al. "Virulence gene sequencing highlights similarities and differences in sequences in Listeria monocytogenes serotype $1 / 2 \mathrm{a}$ and $4 \mathrm{~b}$ strains of clinical and food origin from 3 different geographic locations". Frontiers in Microbiology 9 (2018).

23. Chenal-Francisque V., et al. "Worldwide distribution of major clones of listeria monocytogenes". Emerging Infectious Diseases 17.6 (2011) 1110-1112.

24. Şanlıbaba P., et al. "Prevalence and antibiotic resistance of listeria monocytogenes isolated from ready-to-eat foods in Turkey". Journal of Food Quality (2018).

25. Olaimat AN., et al. "Emergence of Antibiotic Resistance in Listeria monocytogenes Isolated from Food Products: A Comprehensive Review". Comprehensive Reviews in Food Science and Food Safety 17.5 (2018): 1277-1292.

26. Archer DL. "The evolution of FDA's policy on Listeria monocytogenes in ready-to-eat foods in the United States". Current Opinion in Food Science 20 (2018): 64-68.

27. Borucki MK and Call DR. "Listeria monocytogenes Serotype Identification by PCR". Journal of Clinical Microbiology 41 (2003): 5537-5540.

28. http://www.oecd.org/coronavirus/policy-responses/foodsupply-chains-and-covid-19-impacts-and-policy-lessons71b57aea/

29. https://www.foodnavigator.com/Article/2018/01/24/EFSAlooks-at-reasons-behind-increasing-Listeria-incidence

30. Smith AM., et al. "Outbreak of Listeria monocytogenes in South Africa, 2017-2018: Laboratory Activities and Experiences Associated with Whole-Genome Sequencing Analysis of Isolates". Foodborne Pathogens and Disease 16 (2019): 524-530.

31. http://disinfectants.defra.gov.uk/DisinfectantsExternal/Default.aspx?Module=ApprovalsList_SI

\section{Assets from publication with us}

- Prompt Acknowledgement after receiving the article

- Thorough Double blinded peer review

- Rapid Publication

- Issue of Publication Certificate

- High visibility of your Published work

Website: www.actascientific.com/

Submit Article: www.actascientific.com/submission.php

Email us: editor@actascientific.com

Contact us: +919182824667 